\title{
Mutation at $\beta$-Tubulin Codon 200 Indicated Thiabendazole Resistance in Penicillium digitatum Collected from California Citrus Packinghouses
}

\author{
Leigh S. Schmidt, Jennifer M. Ghosoph, Dennis A. Margosan, and Joseph L. Smilanick, USDA-ARS, San Joa- \\ quin Valley Agricultural Sciences Center, 9611 South Riverbend Avenue, Parlier CA 93648
}

\begin{abstract}
Schmidt, L. S., Ghosoph, J. M., Margosan, D. A., and Smilanick, J. L. 2006. Mutation at $\beta$ tubulin codon 200 indicated thiabendazole resistance in Penicillium digitatum collected from California citrus packinghouses. Plant Dis. 90:765-770.

Thiabendazole (TBZ) is commonly applied to harvested citrus fruit in packinghouses to control citrus green mold, caused by Penicillium digitatum. Although TBZ is not used before harvest, another benzimidazole, thiophanate methyl, is commonly used in Florida and may be introduced soon in California to control postharvest decay of citrus fruit. Isolates from infected lemons and oranges were collected from many geographically diverse locations in California. Thirty-five isolates collected from commercial groves and residential trees were sensitive to TBZ, while 19 of 74 isolates collected from 10 packinghouses were resistant to TBZ. Random amplified polymorphic DNA analysis indicated that the isolates were genetically distinct and differed from each other. Nineteen TBZ-resistant isolates and a known TBZ-resistant isolate displayed a point mutation in the $\beta$-tubulin gene sequence corresponding to amino acid codon position 200. Thymine was replaced by adenine (TTC $\rightarrow$ TAC), which changed the phenylalanine (F) to tyrosine (Y). In contrast, for 49 TBZ-sensitive isolates that were sequenced, no mutations at this or any other codon positions were found. All of the isolates of $P$. digitatum resistant to TBZ collected from a geographically diverse sample of California packinghouses appeared to have the same point mutation conferring thiabendazole resistance.
\end{abstract}

Citrus green mold, caused by Penicillium digitatum (Pers.:Fr.) Sacc., is an important postharvest disease of fresh citrus fruit, particularly in arid growing regions (19). The fungicides most commonly used to combat this disease in California are thiabendazole (TBZ) and imazalil (IMZ). The mode of action of TBZ (2-[4thiazolyl] benzimidazole) was shown to be the disruption of microtubule assembly in competition binding studies with carbendazim and TBZ with $P$. expansum (13). These and all benzimidazoles are commonly recognized as essential fungal antitubulin agents $(11,12,24,29)$.

Benzimidazoles bind to the fungal $\beta$ tubulin molecule, as shown for Aspergillus nidulans $(10,12,13,29)$, P. expansum (13), and Rhynchosporium secalis (25), disrupting microtubule assembly and interfering with cell division during mitosis. Point mutations at the site of action inhibit this conformational change that results in microtubule resistance to inhibition by TBZ $(14,36)$. Mutations in specific amino

Corresponding author: Joseph L. Smilanick

E-mail: Jsmilanick@ fresno.ars.usda.gov

Accepted for publication 19 January 2006.

DOI: 10.1094/PD-90-0765

This article is in the public domain and not copyrightable. It may be freely reprinted with customary crediting of the source. The American Phytopathological Society, 2006. acids that confer benzimidazole resistance occur at codon 165 in A. nidulans (29), codon 198 in $P$. expansum, $P$. puberulum, $P$. digitatum, $P$. viridicatum, Monilinia fructicola, and Sclerotinia homoeocarpa (32), and 198 or 200 in P. italicum, P. aurantiogriseum, Venturia inaequalis, $V$. pirina (32), and Botrytis cinerea (44). Mutations reported to confer TBZ resistance in $P$. expansum differ and are more complex. Scholberg and coworkers (40) reported that five resistant isolates had mutations at codon 198, where the amino or valine, while seven other resistant isolates had not changed at this codon and other mutations were not found. Baraldi and coworkers (1) reported mutations at codons 198 and 200 conferred resistance, although one isolate with a mutation at codon 200 was sensitive. Among resistant isolates, the mutation at codon 198 changed the amino acid from glutamic acid to alanine, valine, or lysine. One resistant isolate had a mutation at codon 167 rather than codon 198. The mechanism of benzimidazole resistance among resistant isolates of $P$. digitatum has been little studied. In a previous study, two benomylresistant isolates of this pathogen had mutations at codon 198 that changed the amino acid from glutamic acid to lysine (32).

TBZ has been used in California as a postharvest treatment since $1968(19,23)$. Following the detection of TBZ resistance acid changed from glutamic acid to alanine among $P$. digitatum isolates in California (9) and elsewhere $(6,7)$, imazalil was introduced to control resistant isolates in 1981 (20). It is currently a common practice to apply both TBZ and IMZ to citrus fruit on packinglines either in sequence or together (2-4). Prolonged use of TBZ and IMZ in packinghouses is conducive to the selection and proliferation of resistant isolates of $P$. digitatum (27). TBZ resistance was reported many times among isolates collected in packinghouses $(6,7,17,21,23,26-28)$. While benzimidazole resistance has long been a problem in packinghouses, presumably it may already exist at a low frequency or develop in the future in California citrus groves as well. Neither TBZ nor any other benzimidazole fungicide is applied to citrus groves in California at this time. However, the benzimidazole thiophanate methyl applied in groves before harvest effectively controls postharvest decay of citrus fruit $(31,38,42)$, and regulatory approval for its use is in progress in California. As would be expected, resistant isolates of $P$. digitatum became common among infected fruit from groves where benzimidazoles had been applied for several years to trees before harvest (33). Interestingly, some resistant isolates were found in groves where neither TBZ nor other benzimidazoles had been used $(23,33)$.

The purpose of this study was to collect $P$. digitatum isolates from infected citrus fruits from California packinghouses and citrus groves, to assess their resistance level to TBZ, identify sensitive and resistant phenotypes, and investigate the genetic basis of TBZ resistance. Genetic fingerprinting using random amplified polymorphic DNA (RAPD analysis) ensured that those isolates selected for $\beta$ tubulin sequencing were unique genotypes. A 781-bp region of the $\beta$-tubulin gene was sequenced to identify mutations relevant to amino acid codon positions $165,167,198$, and 200. These sequences were compared with those previously identified from fungi, including a benomyl-sensitive $P$. digitatum isolate (EMBL::D78154), and any changes in the sequence compared with their phenotypic classification.

\section{MATERIALS AND METHODS}

Collection of $P$. digitatum isolates. $P$. digitatum isolates were collected by the method of Holmes and Eckert (27) from infected lemons or oranges from six pack- 
inghouses in Southern California $(n=50$ isolates) and four packinghouses in the Central San Joaquin Valley $(n=24$ isolates) in 2004 and 2005. In addition, $P$. digitatum isolates were collected from locations in the Sacramento Valley, Central San Joaquin Valley, and Southern California from fallen fruit under trees in both commercial groves ( $n=24$ isolates) and residential neighborhoods ( $n=11$ isolates). A single infected fruit was collected under each sampled tree, the fruit was placed in a sterile sealable plastic bag, its location was recorded, and it was transported to the laboratory. Under aseptic conditions, conidia were collected from decay lesions using a sterile toothpick, and the conidia were transferred to potato dextrose agar (PDA; Difco Laboratories, Detroit, MI) plates, which were incubated at $24^{\circ} \mathrm{C}$. A single germinated conidium was selected from this culture, transferred to fresh PDA, and cultured at $24^{\circ} \mathrm{C}$.

Determination of fungicide sensitivity. An $\mathrm{EC}_{50}$ value for all isolates, defined as the TBZ concentration of a fungicide that reduced colony diameter by $50 \%$ on PDA, was determined. The $\mathrm{pH}$ of the PDA was $5.6 \pm 0.2$ in all tests. Isolates were cultured 1 week at $20^{\circ} \mathrm{C}$ on PDA; then conidia were dislodged from the surface of the colony with a glass rod after the addition of a small volume of sterile water with $0.05 \%$ (wt/vol) Triton X-100 surfactant, filtered through two layers of cheesecloth, transferred into a sterile flask, and the conidial suspension was adjusted with sterile water to an optical density of 0.1 at $425 \mathrm{~nm}$ using a spectrophotometer. The suspension contained about $10^{6}$ conidia per ml. A $10-\mu l$ droplet of the conidial suspension was placed on PDA (6 isolates/plate) amended with TBZ at $0,0.05,0.1,1,10$, or $25 \mu \mathrm{g}$ $\mathrm{ml}^{-1}$. After incubation for 4 days at $25^{\circ} \mathrm{C}$, colony diameters were measured, and the concentration that caused a $50 \%$ reduction in colony diameter was calculated by fitting the TBZ concentrations and colony diameters to a sigmoidal curve. The experiment was repeated three times. Sensitive (S) phenotypes were those that could not grow at concentrations of $0.2 \mu \mathrm{g} \mathrm{ml} \mathrm{m}^{-1}$

Table 1. Origin of isolates collected from California packinghouses and citrus trees and the history of thiabendazole (TBZ) use

\begin{tabular}{|c|c|c|c|}
\hline Origin of isolates & TBZ use $^{\mathrm{a}}$ & $\begin{array}{c}\text { Total } \\
\text { isolates }\end{array}$ & $\begin{array}{c}\text { Resistant } \\
\text { isolates }\end{array}$ \\
\hline Fowler - Central San Joaquin Valley & A & 10 & 6 \\
\hline Porterville - Central San Joaquin Valley & A & 3 & 1 \\
\hline Terra Bella - Central San Joaquin Valley & A & 3 & 1 \\
\hline Santa Paula - Southern California & A & 10 & 8 \\
\hline Saticoy - Southern California & A & 4 & 0 \\
\hline Ivanhoe - Central San Joaquin Valley & $\mathrm{B}$ & 8 & 1 \\
\hline Montalvo - Southern California & $\mathrm{B}$ & 9 & 0 \\
\hline Oxnard - Southern California & $\mathrm{B}$ & 8 & 0 \\
\hline Saticoy - Southern California & B & 9 & 0 \\
\hline Ventura - Southern California & B & 10 & 2 \\
\hline Tree $^{\mathrm{b}}$ - Sacramento Valley (Orland, Oroville area) & $\mathrm{C}$ & 12 & 0 \\
\hline Tree $^{b}$ - Central San Joaquin Valley & $\mathrm{C}$ & 19 & 0 \\
\hline Tree $^{\mathrm{b}}$ - Southern California & $\mathrm{C}$ & 4 & 0 \\
\hline Total isolates & & 109 & 19 \\
\hline
\end{tabular}

${ }^{\mathrm{a}} \mathrm{A}=\mathrm{TBZ}$ in use at the time of collection; $\mathrm{B}=\mathrm{TBZ}$ not in use at the time of collection, use in past probable; $\mathrm{C}=$ no history of $\mathrm{TBZ}$ or other fungicide use.

${ }^{\mathrm{b}}$ Isolates were collected from either commercial groves or residential neighborhoods.

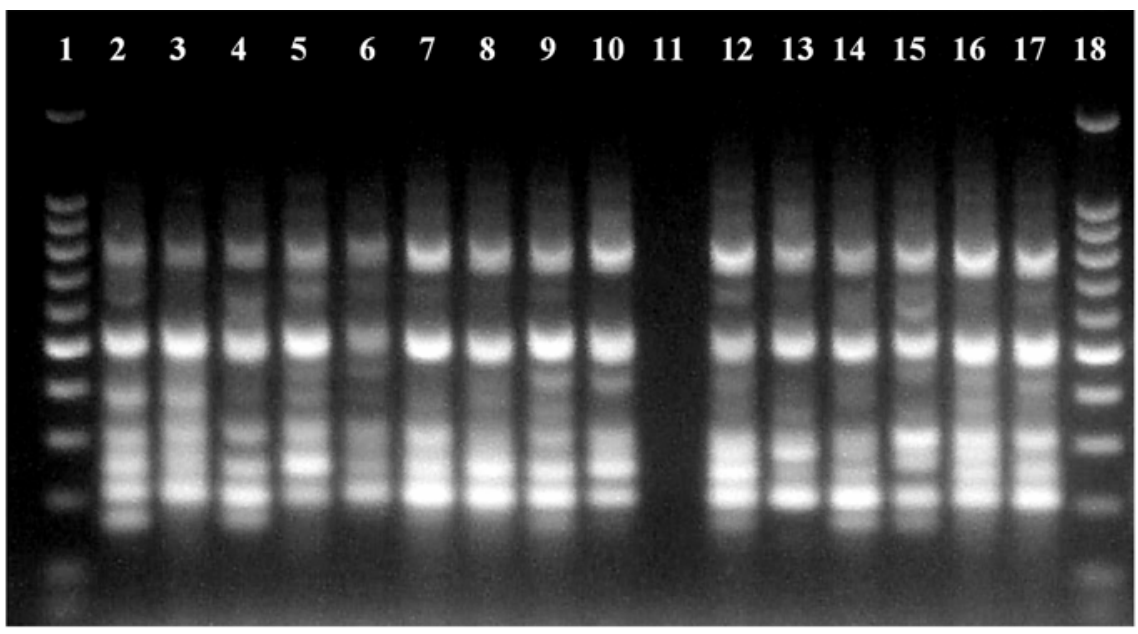

Fig. 1. An agarose gel with individual fingerprint profiles of Penicillium digitatum isolates from random amplified polymorphism DNA analysis using primer omt1. Lanes 1 and 18 each contain a 100-bp marker, lane 11 is a negative control, and lanes 2 to 10 and 12 to 17 are profiles from $P$. digitatum isolates.
TBZ after 5 days at $20^{\circ} \mathrm{C}$, while resistant (R) phenotypes grew at concentrations that exceeded $10 \mu \mathrm{g} \mathrm{ml}^{-1}$. Eckert and Wild (21) stated the discriminatory concentration of TBZ to classify isolates of $P$. digitatum as resistant to TBZ was $10 \mu \mathrm{g} \mathrm{ml}^{-1}$; if an isolate was capable of growth on agar media amended with this fungicide concentration, it was poorly controlled by TBZ applied commercially at maximum rates to citrus fruit (21). Two other isolates that we did not collect were also characterized: TBZresistant isolate D201 (a gift of David Sorenson of Sunkist Growers) and TBZsensitive isolate M6R (a gift of J. W. Eckert, University of California, Riverside).

Isolation of fungal DNA. All reagents were purchased from Sigma Aldrich Co. (St. Louis, MO) unless indicated otherwise. To obtain fungal mycelia, conidia from isolates were collected from 10-dayold colonies, cultured on PDA, and then several milligrams of conidia were placed into Erlenmeyer flasks containing $15 \mathrm{ml}$ of potato dextrose broth (PDB; Difco Laboratories, Detroit, MI) that contained $50 \mu \mathrm{g}$ $\mathrm{ml}^{-1}$ each of chloramphenicol and penicillin G. After shaking for $24 \mathrm{~h}$ at $27^{\circ} \mathrm{C}$, the mycelia were collected and placed into sterile 1.5-ml Eppendorf tubes. The tubes were submerged in liquid nitrogen for $30 \mathrm{~s}$ to freeze the mycelia, then thawed in a $55^{\circ} \mathrm{C}$ water bath and refrozen with liquid nitrogen. Immediately following freezing, the mycelia were crushed using a sterile micropestle, and $0.5 \mathrm{ml}$ of warm $\left(65^{\circ} \mathrm{C}\right)$ cetyltrimethylammonium bromide (CTAB) buffer was added that contained $1 \%$ CTAB, $700 \mathrm{mM} \mathrm{NaCl}, 50 \mathrm{mM}$ Tris- $\mathrm{HCl}$, $\mathrm{pH}$ 8.0, $10 \mathrm{mM}$ EDTA, and $1 \% \quad \beta$ mercaptoethanol. A standard DNA extraction protocol was followed as described by Chen and Ronald (8), with slight modifications. The tubes were vortexed for $5 \mathrm{~min}$ after adding $0.5 \mathrm{ml}$ chloroform:isoamyl alcohol (24:1), then centrifuged at 10,000 $\times g$ for $10 \mathrm{~min}$. The aqueous phase was added to an equal amount of room temperature isopropanol and gently mixed by inversion of the tubes several times. The tubes were centrifuged at $12,000 \times g$ for 4 min; the supernatant was poured off, and the pellet was dried in air. The pellet was washed three times in $0.5 \mathrm{ml}$ of $70 \%$ ethanol and centrifuged each time at $12,000 \times$ $g$ for $4 \mathrm{~min}$. Pellets were dried for at least $15 \mathrm{~min}$ in air and re-suspended in $0.1 \mathrm{ml}$ of Tris-EDTA (TE; $50 \mathrm{mM}$ Tris-HCl, $10 \mathrm{mM}$ EDTA, pH 8.0) and $20 \mu \mathrm{g} \mathrm{ml}^{-1}$ RNase. The DNA was quantified spectrophotometrically as described by Sambrook and Russell (39) and stored at $-80^{\circ} \mathrm{C}$.

RAPD fingerprinting. RAPD primers were obtained from Invitrogen (Carlsbad, CA). The primers G02 and I06 (18), pen (37), ari1, nor1, and omt1 (22) were selected from previous studies of Penicillium spp. and initially screened against genomic DNA of two $P$. digitatum isolates. Omt1 
was selected on the basis that it generated polymorphic bands. The 25- $\mu$ l PCR mixture contained: $1 \mu \mathrm{l}(75 \mathrm{pmol})$ of primer omt1, 5' GTGGACGGACCTAGTCCGACATCAC 3', $0.5 \mu \mathrm{l}(5 \mathrm{ng})$ of template DNA, $2 \mu \mathrm{l}$ of $0.6 \%$ bovine serum albumin (BSA), $12.5 \mu$ of PCR Master Mix (Roche Applied Science, Indianapolis, IN), and 9 $\mu \mathrm{l}$ of sterile distilled water. The reactions were performed in an Eppendorf Mastercycler thermocycler (Hamburg, Germany) with conditions that consisted of an initial denaturation at $96^{\circ} \mathrm{C}$ for $8 \mathrm{~min}$ followed by 42 cycles of $95^{\circ} \mathrm{C}$ for $1 \mathrm{~min}, 40^{\circ} \mathrm{C}$ for 3 min, and $72^{\circ} \mathrm{C}$ for $4 \mathrm{~min}$, with a final extension at the end of these cycles of $72^{\circ} \mathrm{C}$ for $10 \mathrm{~min}$. A $10-\mu \mathrm{l}$ volume of the product was electrophoresed on a $2 \%$ molecular biology grade agarose gel in TE buffer at 85 volts for 90 to $120 \mathrm{~min}$. A 100-bp ladder (G210A; Promega, Madison, WI) was used as a standard. The gel was placed in a dilute solution of ethidium bromide $(0.5 \mu \mathrm{g}$ $\mathrm{ml}^{-1}$ ) for $10 \mathrm{~min}$ and destained in distilled water for $20 \mathrm{~min}$. The bands were visualized under UV light and digitized (Alpha Imager 2000; Alpha Innotech Corp. San Leandro, CA). The RAPD analysis was repeated three times for each isolate.

Analysis of RAPD-PCR reactions. All bands were compared against a 100-bp ladder for size and scored as either 0 or 1 , indicating either the absence or presence of a band, respectively. The binary data from RAPD-PCR fingerprinting grouped the isolates according to the relatedness of banding patterns using hierarchical cluster analysis with squared Euclidian distance and between groups linkage (SPSS version 11.5, SPSS Inc., Chicago, IL).

$\beta$-tubulin gene sequence. A $1,000-b p$ segment of the $\beta$-tubulin gene (15) was amplified, which covered the 165,167 , 198, and 200 amino acid codon positions using the forward primer Bt-T2m-Up and reverse primer Bt-LEV-Lo1 and PCR cycling parameters as described by de Jong et al. (15). Each 50- $\mu$ l reaction contained 4 $\mu \mathrm{l}$ (40 ng) of template DNA, $1 \mu \mathrm{l}$ of each primer $(67$ pmol forward; 56 pmol reverse), $25 \mu$ l of PCR Master Mix (Roche Applied Science, Indianapolis, IN), $4 \mu \mathrm{l}$ of $0.6 \% \mathrm{BSA}$, and $15 \mu \mathrm{l}$ of sterile distilled water. PCR products were electrophoresed on a $1 \%$ agarose gel, then gel purified using DNA Gel Extraction Kit (Montáge, Bedford, MA), and cycle-sequenced on both strands using the PCR conditions of Jung and Oakley (29), and read on an ABI 3730 DNA Analyzer (Applied Biosystems Inc., Foster City, CA). The sequences were then compared to previously published $\beta$ tubulin sequences (GenBank, available online).

\section{RESULTS}

TBZ-S and TBZ-R phenotypes. The $\mathrm{EC}_{50} \mathrm{TBZ}$ concentrations among isolates were in two classes, less than $0.2 \mu \mathrm{g} \mathrm{ml}^{-1}$ and 10 to $25 \mu \mathrm{g} \mathrm{ml}^{-1}$, that corresponded to

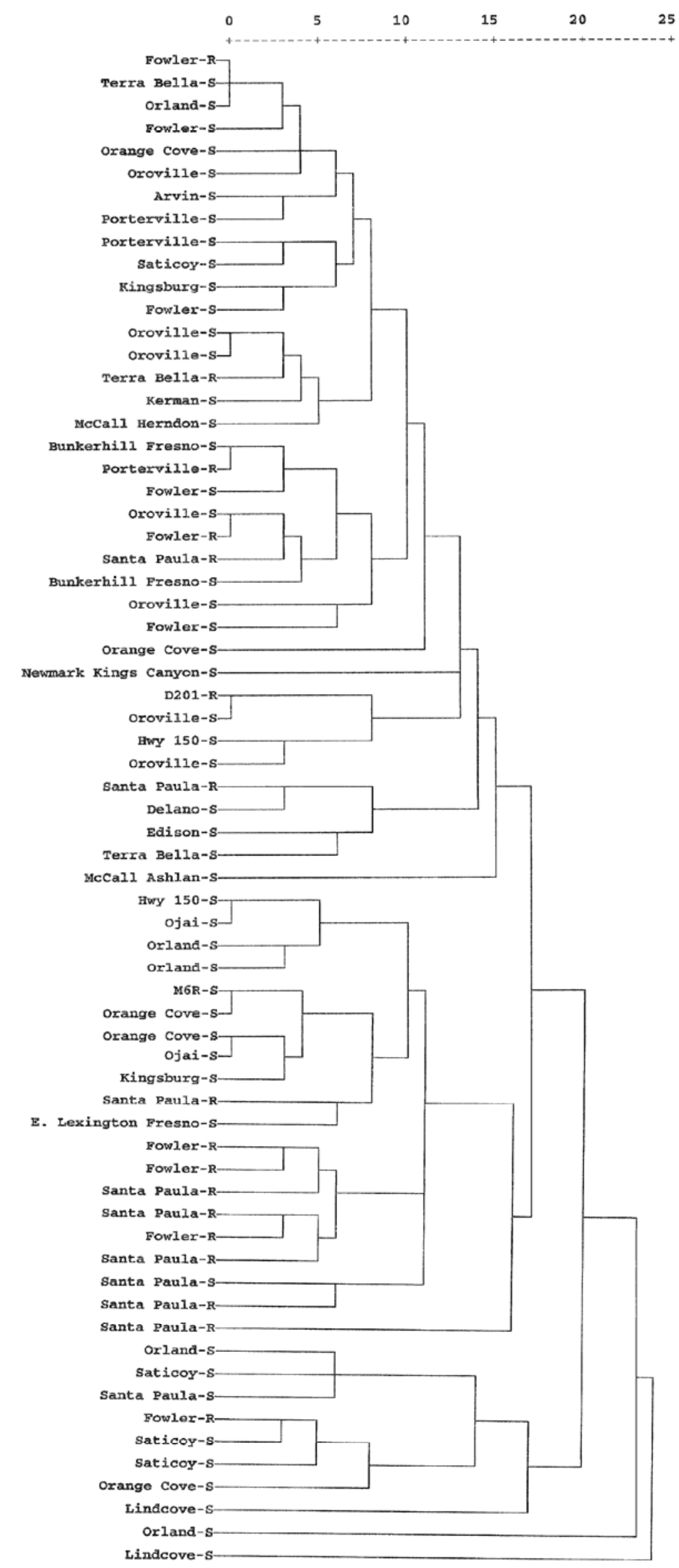

Fig. 2. Hierarchical cluster analysis of random amplified polymorphism DNA banding patterns from thiabendazole (TBZ) sensitive (S) and TBZ resistant (R) Penicillium digitatum phenotypes collected from citrus fruit from trees or packinghouses. Isolates were scored by the presence (1) or absence (0) of bands, and the dendrogram was generated using squared Euclidean distance. 
our classifications of sensitive and resistant isolates, respectively. No isolates were found with intermediate levels of TBZ resistance. Among the 35 isolates collected from commercial groves and trees in residential areas, with no history of fungicide use, the $\mathrm{EC}_{50}$ concentrations for all did not exceed $0.2 \mu \mathrm{g} \mathrm{ml}^{-1}$ of TBZ and no resistant phenotypes were found (Table 1). Among 26 isolates collected from citrus packinghouses actively using TBZ at the time of collection, the $\mathrm{EC}_{50}$ of 16 isolates was 10 to $25 \mu \mathrm{g} \mathrm{ml}^{-1}$ of TBZ, and these were classified as resistant phenotypes, while the $\mathrm{EC}_{50}$ of the remaining isolates did not exceed $0.2 \mu \mathrm{g} \mathrm{ml}^{-1}$ of TBZ, and they were classified as sensitive to TBZ. Three additional resistant isolates were collected from packinghouses where TBZ was not in use at the time of collection; however, there was a probable history of TBZ use at these facilities.

RAPD analysis. As shown by RAPD analysis using omt1, all isolates presented a common band of approximately 500 and $800 \mathrm{bp}$; however, there was a notable variation in the other bands from 175 to $500 \mathrm{bp}$ in length (Fig. 1). Isolates with identical fingerprints occurred among some that were collected at the same time and location, indicating they were clones of the same isolate, and the presumed duplicate isolates were omitted from further characterization. Hierarchical cluster analysis (SPSS 11.5) of the banding patterns produced one large cluster, with many isolates presenting a unique banding pattern, which indicated a high degree of heterogeneity within the $P$. digitatum population in California (Fig. 1). Some isolates collected from distant locations from each other had similar fingerprints. For example, the fingerprints of Fowler-R, Terra Bella-S, and Orland-S were similar (Fig. 2); however, the distance between each collection site was $150 \mathrm{~km}$ and 470 $\mathrm{km}$, respectively. Similarly, the isolate pairs from BunkerhillFresno-S and Porterville-R, Oroville-S and Fowler-R, D201 and Oroville-S, Hway150-S and Ojai-S, M6R and Orangecove-S, and Orangecove$\mathrm{S}$ and Ojai-S had identical banding patterns, but were from different areas. One exception occurred between two sensitive isolates from the Oroville area of the Sacramento Valley, which had identical RAPD banding patterns, suggesting that these two isolates may have been the same genotype (Fig. 2).

Sequencing of the $\beta$-tubulin gene of TBZ-R and TBZ-S phenotypes. The 20 resistant phenotypes and 49 sensitive phenotypes, encompassing all collection areas and showing unique RAPD banding patterns, were chosen for sequencing of the $\beta$ tubulin gene. The selection of 49 sensitive isolates included those from packinghouses (two isolates each from Saticoy, Santa Paula, Porterville, and Terra Bella, four from Ventura, five from Oxnard, and six from Montalvo) and those from trees (three from Southern California, six from the Central San Joaquin Valley, and seven from the Sacramento Valley). A region of the $\beta$-tubulin gene, incorporating those nucleotides corresponding with amino acids 165 to 200, was sequenced on both the forward and reverse strands, using primers Bt-T2m-Up and Bt-LEV-Lo1 (15).
The resulting partial $\beta$-tubulin sequence from each representative isolate was compared with the previously submitted fungal $\beta$-tubulin amino acid sequences including Aspergillus nidulans, Botrytis cinerea, and a benomyl-sensitive strain of $P$. digitatum (Table 2). Every one of the $P$. digitatum-R isolates had a single transversion point mutation at nucleotide position 254 , where thymine was replaced by adenine (TTC $\rightarrow$ TAC), relating to amino acid codon 200 , which changed phenylalanine $(\mathrm{F})$ to tyrosine (Y) (Tables 2 and 3). No mutations were found in the sequence (which related to codon positions $165,167,198$, and 200) of all $49 P$. digitatum-S isolates. The $\beta$ tubulin gene sequence from a representative sensitive and resistant $P$. digitatum isolate, PD2 and PD38 correspondingly, revealed 100 and $99 \%$ homologies, respectively, to that of $P$. digitatum (GenBank accession no. D78154), with the single nucleotide difference in the PD38 at nucleotide position 1312. The GenBank accession numbers of the partial $\beta$-tubulin gene sequences of PD2 (representing the 49 TBZ-sensitive isolates) and PD38 (representing the 20 TBZ-resistant isolates) were DQ084020 and DQ084021, respectively.

\section{DISCUSSION}

The importance of specific amino acids in fungal tubulin with respect to benzimi-

Table 3. Point mutations and deduced amino acid substitutions in the $\beta$-tubulin gene of Penicillium digitatum isolates collected from citrus from trees or packinghouses that were sensitive or resistant to thiabendazole (TBZ) as indicated by their minimum inhibitory TBZ concentration (MIC)

\begin{tabular}{lcclc}
\hline $\begin{array}{l}\boldsymbol{P} \text {. digitatum } \\
\text { isolates sequenced }\end{array}$ & $\begin{array}{c}\text { TBZ MIC } \\
(\boldsymbol{\mu g} / \mathbf{m l})^{\mathbf{a}}\end{array}$ & Phenotype & $\begin{array}{c}\text { Nucleotide } \\
\text { substitution }\end{array}$ & $\begin{array}{c}\text { Codon } \\
\text { position 200 }\end{array}$ \\
\hline 49 & $0.05-1.00$ & $\mathrm{~S}$ & None & Phe \\
20 & $10.00-20.00$ & $\mathrm{R}$ & TTC to TAC & Tyr \\
\hline
\end{tabular}

a TBZ sensitive $(\mathrm{S})$ and TBZ resistant $(\mathrm{R})$ phenotypes had $\mathrm{EC}_{50} \mathrm{TBZ}$ concentrations of $\leq 0.2 \mu \mathrm{g} \mathrm{ml} \mathrm{m}^{-1}$ and $\geq 10 \mu \mathrm{g} \mathrm{ml}^{-1}$, respectively, on amended potato dextrose agar as determined by colony diameter.

Table 2. Multiple sequence alignment of $\beta$-tubulin protein, from amino acid residues 166 to 240, from Aspergillus nidulans (EMBL::M17519), Botrytis cinerea (EMBL::Z69263), Penicillium digitatum benomyl sensitive (EMBL::D78154), P. digitatum-sensitive (S) isolates $(n=49)$, and P. digitatum-resistant (R) isolates $(n=20)^{\mathrm{a}}$

\begin{tabular}{|c|c|c|c|c|c|c|c|c|c|c|c|c|c|c|c|c|c|c|c|c|c|c|c|c|c|}
\hline & 166 & & & & & & & & & & & & & & & & & & & & & & & & 190 \\
\hline Aspergillus nidulans & $\mathrm{T}$ & $\mathrm{F}$ & $\mathrm{S}$ & $\mathrm{V}$ & $\mathrm{V}$ & $\mathrm{P}$ & $\mathrm{S}$ & $\mathrm{P}$ & $\mathrm{K}$ & $\mathrm{V}$ & $\mathrm{S}$ & $\mathrm{D}$ & $\mathrm{T}$ & $\mathrm{V}$ & $\mathrm{V}$ & $\mathrm{E}$ & $\mathrm{P}$ & $\mathrm{Y}$ & $\mathrm{N}$ & A & $\mathrm{T}$ & $\mathrm{L}$ & $\mathrm{S}$ & $\mathrm{V}$ & $\mathrm{H}$ \\
\hline Botrytis cinerea & $\mathrm{T}$ & $\mathrm{F}$ & $\mathrm{S}$ & $\mathrm{V}$ & $\mathrm{V}$ & $\mathrm{P}$ & $\mathrm{S}$ & $\mathrm{P}$ & $\mathrm{K}$ & $\mathrm{V}$ & $\mathrm{S}$ & $\mathrm{D}$ & $\mathrm{T}$ & $\mathrm{V}$ & $\mathrm{V}$ & $\mathrm{E}$ & $\mathrm{P}$ & $\mathrm{Y}$ & $\mathrm{N}$ & A & $\mathrm{T}$ & $\mathrm{L}$ & $\mathrm{S}$ & $\mathrm{V}$ & $\mathrm{H}$ \\
\hline Penicillium digitatum & $\mathrm{T}$ & $\mathrm{F}$ & $\mathrm{S}$ & $\mathrm{V}$ & $\mathrm{V}$ & $\mathrm{P}$ & $\mathrm{S}$ & $\mathrm{P}$ & $\mathrm{K}$ & $\mathrm{V}$ & $\mathrm{S}$ & $\mathrm{D}$ & $\mathrm{T}$ & $\mathrm{V}$ & $\mathrm{V}$ & $\mathrm{E}$ & $\mathrm{P}$ & $\mathrm{Y}$ & $\mathrm{N}$ & A & $\mathrm{T}$ & $\mathrm{L}$ & $\mathrm{S}$ & $\mathrm{V}$ & $\mathrm{H}$ \\
\hline$P$. digitatum $-\mathrm{S}$ & $*$ & $*$ & $*$ & $*$ & $*$ & $*$ & $*$ & $*$ & $*$ & $*$ & $*$ & $*$ & $*$ & $*$ & $*$ & $*$ & $*$ & $*$ & $*$ & $*$ & $*$ & $*$ & $*$ & $*$ & $*$ \\
\hline \multirow[t]{2}{*}{$P$ digitatum $-\mathrm{R}$} & $*$ & $*$ & $*$ & $*$ & $*$ & $*$ & $*$ & $*$ & $*$ & $*$ & $*$ & $*$ & $*$ & $*$ & $*$ & $*$ & $*$ & $*$ & $*$ & $*$ & $*$ & $*$ & $*$ & $*$ & $*$ \\
\hline & 191 & & & & & & & 198 & & 200 & & & & & & & & & & & & & & & 215 \\
\hline Aspergillus nidulans & Q & $\mathrm{L}$ & $\mathrm{V}$ & $\mathrm{E}$ & $\mathrm{H}$ & S & $\mathrm{D}$ & $\mathrm{E}$ & $\mathrm{T}$ & $\mathrm{F}$ & $\mathrm{C}$ & I & $\mathrm{D}$ & $\mathrm{N}$ & $\mathrm{E}$ & A & $\mathrm{L}$ & $\mathrm{Y}$ & $\mathrm{D}$ & I & $\mathrm{C}$ & M & $\mathrm{R}$ & $\mathrm{T}$ & $\mathrm{L}$ \\
\hline Botrytis cinerea & $\mathrm{Q}$ & $\mathrm{L}$ & $\mathrm{V}$ & $\mathrm{E}$ & $\mathrm{H}$ & S & $\mathrm{D}$ & $\mathrm{E}$ & $\mathrm{T}$ & $\mathrm{F}$ & $\mathrm{C}$ & I & $\mathrm{D}$ & $\mathrm{N}$ & $\mathrm{E}$ & $\mathrm{A}$ & $\mathrm{L}$ & $\mathrm{Y}$ & $\mathrm{D}$ & I & $\mathrm{C}$ & $\mathrm{M}$ & $\mathrm{R}$ & $\mathrm{T}$ & $\mathrm{L}$ \\
\hline Penicillium digitatum & $\mathrm{Q}$ & $\mathrm{L}$ & $\mathrm{V}$ & $\mathrm{E}$ & $\mathrm{H}$ & S & $\mathrm{D}$ & $\mathrm{E}$ & $\mathrm{T}$ & $\mathrm{F}$ & $\mathrm{C}$ & I & $\mathrm{D}$ & $\mathrm{N}$ & $\mathrm{E}$ & A & $\mathrm{L}$ & $\mathrm{Y}$ & $\mathrm{D}$ & I & $\mathrm{C}$ & M & $\mathrm{R}$ & $\mathrm{T}$ & $\mathrm{L}$ \\
\hline P. digitatum $-\mathrm{S}$ & $*$ & $*$ & $*$ & $*$ & $*$ & $*$ & $*$ & $*$ & $*$ & $\mathrm{~F}$ & $*$ & $*$ & $*$ & $*$ & $*$ & $*$ & $*$ & $*$ & $*$ & $*$ & $*$ & $*$ & $*$ & $*$ & $*$ \\
\hline \multirow[t]{2}{*}{$P$ digitatum $-\mathrm{R}$} & $*$ & $*$ & $*$ & $*$ & $*$ & $*$ & $*$ & $*$ & $*$ & $\mathrm{Y}$ & $*$ & $*$ & $*$ & $*$ & $*$ & $*$ & $*$ & $*$ & $*$ & $*$ & $*$ & $*$ & $*$ & $*$ & $*$ \\
\hline & 216 & & & & & & & & & & & & & & & & & & & & & & & & 240 \\
\hline Aspergillus nidulans & $\mathrm{K}$ & $\mathrm{L}$ & $\mathrm{S}$ & $\mathrm{N}$ & $\mathrm{P}$ & S & $\mathrm{Y}$ & $\mathrm{G}$ & $\mathrm{D}$ & $\mathrm{L}$ & $\mathrm{N}$ & $\mathrm{H}$ & $\mathrm{L}$ & V & $\mathrm{S}$ & A & $\mathrm{V}$ & M & $\mathrm{S}$ & G & $\mathrm{V}$ & $\mathrm{T}$ & $\mathrm{T}$ & $\mathrm{C}$ & $\mathrm{L}$ \\
\hline Botrytis cinerea & $\mathrm{K}$ & $\mathrm{L}$ & $\mathrm{S}$ & $\mathrm{N}$ & $\mathrm{P}$ & S & $\mathrm{Y}$ & $\mathrm{G}$ & $\mathrm{D}$ & $\mathrm{L}$ & $\mathrm{N}$ & $\mathrm{H}$ & $\mathrm{L}$ & $\mathrm{V}$ & $\mathrm{S}$ & A & $\mathrm{V}$ & M & $\mathrm{S}$ & $\mathrm{G}$ & $\mathrm{V}$ & $\mathrm{T}$ & $\mathrm{T}$ & $\mathrm{C}$ & $\mathrm{L}$ \\
\hline Penicillium digitatum & $\mathrm{K}$ & $\mathrm{L}$ & $\mathrm{S}$ & Q & $\mathrm{P}$ & S & $\mathrm{Y}$ & $\mathrm{G}$ & $\mathrm{D}$ & $\mathrm{L}$ & $\mathrm{N}$ & $\mathrm{H}$ & $\mathrm{L}$ & $\mathrm{V}$ & $\mathrm{S}$ & A & $\mathrm{V}$ & M & $\mathrm{S}$ & $\mathrm{G}$ & $\mathrm{V}$ & $\mathrm{T}$ & $\mathrm{T}$ & $\mathrm{S}$ & $\mathrm{L}$ \\
\hline P. digitatum $-\mathrm{S}$ & $*$ & $*$ & $*$ & $*$ & $*$ & $*$ & $*$ & $*$ & $*$ & $*$ & $*$ & $*$ & $*$ & $*$ & $*$ & $*$ & $*$ & $*$ & $*$ & $*$ & $*$ & $*$ & $*$ & $*$ & . \\
\hline$P$ digitatum $-\mathrm{R}$ & $*$ & $*$ & $*$ & $*$ & $*$ & $*$ & $*$ & $*$ & $*$ & $*$ & $*$ & $*$ & $*$ & $*$ & $*$ & $*$ & $*$ & $*$ & $*$ & $*$ & $*$ & $*$ & $*$ & $*$ & $*$ \\
\hline
\end{tabular}

\footnotetext{
a Asterisk denotes identical residue to above sequence. A single residue change (from phenylalanine to tyrosine) is indicated at position 200 in all thiabenda-
} zole (TBZ)-R isolates, but is absent in all TBZ-S isolates. 
dazole resistance has been well studied $(1,29,32,34,36,40,44)$. All 20 TBZresistant isolates of $P$. digitatum identified in this study had a single mutation that changed the amino acid at codon position 200. This is the first report of TBZ resistance in $P$. digitatum conferred by a codon change at position 200 in the $\beta$-tubulin gene. This result differs from that of Koenraadt and coworkers (32), who reported that benomyl resistance in the two isolates of $P$. digitatum they examined was conferred by a mutation at codon position 198 .

The tubulin gene is highly conserved, with a $\sim 75 \%$ sequence similarity within each family (5); however, there are specific amino acid residues that are repeatedly associated with fungicide resistance $(1,29,32,34,36,40,44)$. The relevance of the residue at codon position 200 of the tubulin gene of Schizosaccharomyces pombe was examined by Paluh and coworkers (36) with respect to the rate of microtubule depolymerization when the codon was changed from phenylalanine to tyrosine, the same change we observed with $P$. digitatum isolates resistant to thiabendazole. They discovered when examining the microtubule dynamics of a mutated (F200Y) S. pombe strain that an interruption in mitosis and a complete failure of meiosis occurred because of the delayed breakdown of the tubulin heterodimer. The crystal structure of the $\beta$-tubulin protein $(35,36)$ displays the residue corresponding to position 200 at the internal interface where the $\alpha$ - and $\beta$-tubulins join to form a heterodimeric molecule, and also adjacent to the GTP binding site (44). The constant cycling of microtubules, referred to as dynamic instability $(30,36)$, involves the polymerization and de-polymerization of the tubulin heterodimers. Many helper proteins, such as chaperones, GTPases, and kinases facilitate microtubule dynamics (41). It has also been suggested that an asymmetric distribution of these proteins, due to a delay in spindle de-polymerization during meiosis (36) caused by the mutation of F200Y, as seen in the P. digitatum TBZ$\mathrm{R}$ isolates, could affect spindle stability. These findings suggest that the internal interface plays a crucial role in one of the following: (i) the stabilization dynamics of the $\alpha$ - and $\beta$-tubulin molecules; (ii) the interaction between the microtubule and GTP; or (iii) uneven distribution of the proteins used in microtubule dynamics.

Phylogenetic work by Detrich et al. (16) verified the importance of phenylalanine at residue 200, pinpointing it as the single consistent sequence difference between cold-stable microtubules (belonging to Antarctic fish) and heat-stable microtubules associated with all homeotherms, such as mammals, where the phenylalanine has been substituted with tyrosine. Fungi have cold-stable microtubules with phenylalanine at position 200; however, the mutation to tyrosine, which is common in all heat-stable microtubules, has been associated with benzimidazole resistance (36). In addition, Wright and Hunter (43) found that cold-stability and benomyl resistance were allele specific in Caenorhabditis elegans. Temperature influenced the benzimidazole sensitivity of some resistant isolates of Aspergillus nidulans $(14,32)$ and Saccharomyces cerevisiae (14). Isolates of Monilinia fructicola, cause of brown rot of stone fruit, that were highly resistant to benomyl lost their resistance at $31^{\circ} \mathrm{C}$, while those isolates with a low level of resistance lost benomyl resistance at $15^{\circ} \mathrm{C}$ (34). Further studies to observe temperature effects on TBZ-R isolates of $P$. digitatum could influence strategies to manage resistant isolates in packinghouses.

Some conclusions from our work include: (i) RAPD patterns of TBZ-R isolates indicated $P$. digitatum populations may be heterogeneous, although more work is needed to analyze diversity in populations of this pathogen. If heterogeneous before TBZ resistance developed, resistance may have developed many times independently and is not the result of a rare mutation that dispersed throughout California. Conversely, TBZ resistance may have developed only once and the diversity among the isolates we observed occurred later; (ii) it is likely a single point mutation at codon 200 of the $\beta$-tubulin gene is responsible for the reduction in competitive fitness associated with benzimidazole resistance that was reported previously $(21,26)$, where resistant isolates of $P$. digitatum collected in California declined rapidly in populations of conidia that developed from citrus fruit co-inoculated with a mixture of benzimidazole-resistant and -sensitive conidia; and (iii) the development of a molecular probe to detect the single point mutation at codon 200 of the $\beta$-tubulin gene of $P$. digitatum is feasible and would facilitate the detection of resistant isolates. The detection of resistant isolates will become particularly important now to monitor TBZ resistance in packinghouses and in the future in groves if grove applications of thiophanate methyl become popular in California. Presumably, isolates resistant to TBZ will also be resistant to thiophanate methyl, but this should be confirmed, because isolates of other Penicillium spp. have been resistant to one but not both fungicides (40). Rigorous monitoring to detect benzimidazole resistance is needed to identify isolates resistant both to this fungicide and to TBZ in coordinated strategies to minimize their development.

\section{ACKNOWLEDGMENTS}

This work was made possible by a grant from the California Citrus Research Board. We thank Franka Miklota Gabler and Monir Mansour for their assistance in the phenotypic classification of the isolates, and Fred Ryan, Deanne Bell, and Alice Wright for the use of laboratory equipment. Thanks also to David Sorenson, Julie Doctor, and Alistair McKay for their aid in the collection of samples, and to all participating grove and packinghouse managers for their cooperation.

\section{LITERATURE CITED}

1. Baraldi, E., Mari, M., Chierici, E., Pondrelli, M., Bertolini, P., and Pratella, G. C. 2003 Studies on thiabendazole resistance of Penicillium expansum of pears: Pathogenic fitness and genetic characterization. Plant Pathol. 52:362-370.

2. Brown, G. E. 1984. Efficacy of citrus postharvest fungicides applied in water or resin solution water wax. Plant Dis. 68:415-418.

3. Brown, G. E., and Dezman, D. J. 1990. Uptake of imazalil by citrus fruit after postharvest application and the effect of residue distribution on sporulation of Penicillium digitatum. Plant Dis. 74:927-930.

4. Brown, G. E., Nagy, S., and Maraulja, M 1983. Residues from postharvest nonrecovery spray applications of imazalil to oranges and effects on green mold caused by Penicillium digitatum. Plant Dis. 67:954-957.

5. Burns, R. G., and Surridge, C. D. 1993. Tubulin: Conservation and structure. Pages 3-31 in Microtubules. J. Hyams and C. Lloyd, eds. Wiley-Liss, New York.

6. Bus, V. G. 1992. $\mathrm{ED}_{50}$ levels of Penicillium digitatum and $P$. italicum with reduced sensitivity to thiabendazole, benomyl and imazalil. Postharv. Biol. Technol. 1:305-315.

7. Bus, V. G., Bongers, A. J., and Risse, L. A. 1991. Occurrence of Penicillium digitatum and $P$. italicum resistant to benomyl, thiabendazole, and imazalil on citrus fruit from different geographic origins. Plant Dis. 75:1098-1100.

8. Chen, D. H., and Ronald, P. C. 1999. A rapid DNA minipreparation method suitable for AFLP and other PCR applications. Plant Mol. Biol. Rep. 17:53-57.

9. Dave, B., Sales, M., and Walia, M. 1989. Resistance of different strains of Penicillium digitatum to imazalil treatment in California citrus packinghouses. Proc. Fla. State. Hortic. Soc. 102:178-179.

10. Davidse, L. C. 1973. Antimitotic activity of methyl benzimidazole-2-yl carbamate (MBC) in Aspergillus nidulans. Pestic. Biochem. Physiol. 3:317-325.

11. Davidse, L. C. 1986. Benzimidazole fungicides: Mechanism of action and biological impact. Annu. Rev. Phytopathol. 24:43-65.

12. Davidse, L. C., and Flach, W. 1977. Differential binding of methyl benzimidazole-2-yl carbamate to fungal tubulin as a mechanism of resistance to this antimitotic agent in mutant strains of Aspergillus nidulans. J. Cell. Biol. $72: 174$

13. Davidse, L. C., and Flach, W. 1978. Interaction of thiabendazole with fungal tubulin. Biochim. Biophysica Acta 543:82-90.

14. Davidse, L. C., and Ishii, H. 1995. Biochemical and molecular aspects of the mechanisms of action of benzimidazoles, N-phenylcarbamates and $\mathrm{N}$-phenylformamidoximes and the mechanism of resistance to these compounds in fungi. Pages 305 to 322 in: Modern Selective Fungicides: Properties, Applications, Mechanisms of Action. H. Lyr, ed. Gustav Fisher Verlag, New York.

15. de Jong, S. N., Lévesque, C. A., Verkley, G. J. M., Abeln, E. C. A., Rahe, J. E., and Braun, P. G. 2001. Phylogenetic relationships among Neofabraea species causing tree cankers and bull's-eye rot of apple based on DNA sequencing of ITS nuclear rDNA, mitochondrial rDNA, and the $\beta$-tubulin gene. Mycol. Res. 105:658-669.

16. Detrich, H. W., III, Parker, S. K., Williams, R C., Jr., Nogales, E., and Downing, K. H. 2000. Cold adaptation of microtubule assembly and dynamics: Structural interpretation of primary 
sequence changes present in the $\alpha$ and $\beta$ tubulins of Antarctic fishes. J. Biol. Chem. 275:37038-37047.

17. Díaz Borrás, M. A., Vila Aguilar, R., and Hernández Giménez, E. 1987. Resistance to sodium $o$-phenylphenol, benomyl, TBZ and CGA-64251 in strains of Penicillium digitatum isolated from Spanish citrus packinghouses. Rev. Agroquim. Tecnol. Aliment. 27:439-445.

18. Dupont, J., Magnin, S., Marti, A., and Brousse, M. 1999. Molecular tools for identification of Penicillium starter cultures used in the food industry. Int. J. Food Microbiol. 49:109-118.

19. Eckert, J. W., and Eaks, I. L. 1989. Postharvest disorders and diseases of citrus fruits. Pages 179-260 in: The Citrus Industry. Vol. 5. W. Reuther, E. C. Calavan, and G. E. Carman, eds. U. Calif. Div. Agric. Nat. Res., Oakland.

20. Eckert, J. W., Sievert, J. R., and Ratnayake, M. 1994. Reduction of imazalil effectiveness against citrus green mold in California packinghouses by resistant biotypes of Penicillium digitatum. Plant Dis. 78:971-974.

21. Eckert, J. W., and Wild, B. L. 1983. Problems of fungicide resistance in Penicillium rot of citrus fruits. Pages 525-556 in: Pest Resistance to Pesticides. G. P. Georghiou and T. Saito, eds. Plenum Publishing Corp., New York.

22. Geisen, R., Cantor, M. D., Hansen, T. K., Holzapfel, W. H., and Jakobsen, M. 2001. Characterization of Penicillium roqueforti strains used as cheese starter cultures by RAPD typing. Int. J. Food Microbiol. 65:183191

23. Harding, P. R., Jr. 1972. Differential sensitivity to thiabendazole by strains of Penicillium italicum and P. digitatum. Plant. Dis. Rep. 56:256260.

24. Holloman, D. W., and Butters, J. A. 1994. Molecular determinants for resistance to crop protection chemicals. Pages 98-110 in: Molecular Biology in Crop Protection. G. Marshall and D. Walters, eds. Chapman and Hall, London.

25. Holloman, D. W., Butters, J. A., Barker, H., and Hall, L. 1998. Fungal $\beta$-tubulin, expressed as a fusion protein, binds benzimidazole and phenylcarbamate fungicides. Antimicrob. Agents Chemother. 42:2171-2173.

26. Holmes, G. J., and Eckert, J. W. 1995. Relative fitness of imazalil-resistant and -sensitive bioypes of Penicillium digitatum. Plant Dis. 79:1068-1073.

27. Holmes, G. J., and Eckert, J. W. 1999. Sensitivity of Penicillium digitatum and P. italicum to postharvest citrus fungicides in California. Phytopathology 89:716-721.

28. Houck, L. G. 1977. Problems of resistance to citrus fungicides. Proc. Int. Soc. Citric. 1:263.

29. Jung, M. K., and Oakley, B. R. 1990. Identification of an amino acid substitution in benA, $\beta$-tubulin gene of Aspergillus nidulans that confers thiabendazole resistance and benomyl supersensitivity. Cell Mot. Cytoskel. 17:87-94.

30. Karp, G. 1999. Cell and Molecular Biology: Concepts and Experiments. 2nd ed. John Wiley $\&$ Sons, New York.

31. Kinay, P., Yildiz, F., Sen, F., Yildiz, M., and Karacali, I. 2005. Integration of pre- and postharvest treatments to minimize Penicillium decay of Satsuma mandarins. Postharv. Biol. Technol. 37:31-36.

32. Koenraadt, H., Somerville, S. C., and Jones, A. L. 1992. Characterization of mutations in the $\beta$-tubulin gene of benomyl-resistant field strains of Venturia inaequalis and other plant pathogenic fungi. Mol. Plant Pathol. 82:13481354

33. Kuramoto, T. 1976. Resistance to benomyl and thiophanate-methyl in strains of Penicillium digitatum and P. italicum in Japan. Plant Dis. Rep. 60:168-172.

34. Ma, Z., Yoshimura, M. A., and Michailides, T. J. 2003. Identification and characterization of benzimidazole resistance in Monilinia fructicola from stone fruit orchards in California. Appl. Environ. Biol. 69:7145-7152.

35. Nogales, E., Wolf, S. G., and Downing, K. H. 1998. Structure of the $\beta$-tubulin dimer by elec- tron crystallography. Nature 391:199-203.

36. Paluh, J. L., Killilea, A. N., Detrich, H. W. 3rd., and Downing, K. H. 2004. Meiosisspecific failure of cell cycle progression in fission yeast by mutation of a conserved $\beta$ tubulin residue. Mol. Biol. Cell 15:1160-1171.

37. Pianzzola, M. J., Moscatelli, M., and Vero, S. 2004. Characterization of Penicillium isolates associated with blue mold on apple in Uruguay. Plant Dis. 88:23-28.

38. Ritenour, M. A., Pelosi, R. R., Burton, M. S., Stover, E. W., Dou, H., and McCollum, T. G. 2004. Assessing the efficacy of preharvest fungicide applications to control postharvest diseases of Florida citrus. HortTechnology 14:58 62.

39. Sambrook, J., and Russell, D. W. 2001. Molecular Cloning: A Laboratory Manual. 3rd ed. Cold Spring Harbor Laboratory, Cold Spring Harbor, NY.

40. Scholberg, P. L., Harlton, C., Haag, P., Lévesque, C. A., Gorman, D. O., and Seifert, K. 2005. Benzimidazole and diphenylamine sensitivity and identity of Penicllium spp. that cause postharvest blue mold of apples using $\beta$ tubulin gene sequences. Postharv. Biol. Technol. 36:41-49.

41. Severson, A. F., and Bowerman, B. 2002 Cytokinesis: Closing in on the central spindle. Develop. Cell 2:4-6.

42. Smilanick, J. L., Mansour, M. F., and Sorenson, D. 2006. Pre- and postharvest treatments to control green mold of citrus fruit dur ing ethylene degreening. Plant Dis. 90:89-96.

43. Wright, A. J., and Hunter, C. P. 2003. Mutations in a $\beta$-tubulin disrupt spindle orientation and microtubule dynamics in the early Caenorhabditis elegans embryo. Mol. Biol Cell 14:4512-4525.

44. Yarden, O., and Katan, T. 1993. Mutations leading to substitutions at amino acids 198 and 200 of beta-tubulin that correlate with benomyl-resistance phenotypes of field strains of Botrytis cinerea. Phytopathology 83:14781483. 